Teknomekanik

Vol.3, No.2, December 2020, pp. 56-61

e-ISSN: 2621-8720 p-ISSN: 2621-9980

\title{
The Effect of AC (alternating current) and DC (direct current) on Bend Testing Results of Low Carbon Steel Welding Joints
}

Zetri Firmanda, Abdul Aziz \& Bulkia Rahim

Jurusan Teknik Mesin, Fakultas Teknik, Universitas Negeri Padang, Indonesia

\begin{tabular}{l} 
Article Info \\
\hline Article history: \\
Received Jun $03^{\text {th }}, 2020$ \\
Revised Aug $09^{\text {th }}, 2020$ \\
Accepted Nov $26^{\text {th }}, 2020$ \\
\hline
\end{tabular}

\section{Keywords:}

SMAW

$\mathrm{AC}$ and DC currents

Bend Testing

Low Carbon Steel

\begin{abstract}
The purpose of this study was to determine the effect of alternating current $(A C)$ and direct current $(D C)$ on the bend testing results of low carbon steel welding joints. The results of this study are expected to determine the cracks that occur from the root bend and face bend testings in the AC and DC welding process. This study used experimental method, where the research was done by giving $A C$ and direct polarity $D C$ (DC-) SMAW welding treatments. The material used in this research was low carbon steel plate DIN 17100 Grade ST 44, thickness 10 with E7016 electrode type. The process of welding joints used a single $V$ seam, strong current of 90A, and the welding position of $1 G$. The testing of welding joints was carried out by bend testing using the standard acceptance of AWS D1.1 root bend and face bend testing results. The results of the bend testing showed that the AC welding root bend test specimen held no cracks while the DC welding root bend test held cracks with incompelete penetration and open crack defects. On the contrary, the AC welding face bend test had open crack defects and in the DC welding face bend test was found a crack. Thus, there was a difference in the crack resistance of the welding joint from the types of current used through the root bend test and face bend test. Therefore, it can be summarized that AC welding is better for root welding and $D C$ welding is good for capping welding.
\end{abstract}

\section{Corresponding Author:}

Zetri Firmanda,

Jurusan Teknik Mesin, Fakultas Teknik, Universitas Negeri Padang

Jln. Prof. Dr. Hamka Air Tawar, Padang (25131), Sumatera Barat, Indonesia

Email: zetrifirmanda9@gmail.com

\section{INTRODUCTION}

The development of production technology using advanced metal raw materials plays a very important role in the use of welding technology. Nowadays, in this industrialization era, the utilization of metal welding technology is widely used for the connection process especially in the engineering sector [1]. In fact, buildings and machines made by welding techniques have the advantage whichthe welding joints result will be strong, tight, and easy to use [2]. One of the connection processes that are often used is Shielded Metal Art Welding (SMAW) or also known as electric arc welding [3]. Electric arc welding is a metal joining process using a heat source from an electric arc flame to melt the metal [4]. There are two types of electric arc welding machines, namely alternating current (AC) electricity and Direct Current (DC) electricity [5]. In the AC welding machine, the heat generated by the ends of the positive and negative poles is equal in proportion (50\%: 50\%), whereas in DC welding machine the heat is generated by $30 \%$ of the positive pole and $70 \%$ of the negative pole [6]. Welding using $\mathrm{AC}$ power has the advantage that $\mathrm{AC}$ power is easier in terms of equipment and maintenance than DC power which is slightly more complicated [7].

There are two types of polarity installation on welding machines, namely straight polarity and reverse polarity [8]. Straight polarity is often called the electric welding cycle with negative electrodes (DC-), while reverse polarity is often referred to the electric welding cycle with positive electrodes (DC+) [9]. The weakness of straight polarity is that the penetration is shallow, whereas the penetration of reverse polarity is deeper [10]. According to Despa's research [6], the depth of penetration, the width and the height of welding path using DC electricity is better than AC. The welding input parameters that influence welding penetration are welding current, welding voltage, and welding speed [11]. Welding parameters are necessary to achieve the desired 
penetration in welding joint [12]. The amount of electric current given can affect the weld area and the strength of the weld metal [13]. The type of seam used also has an impact on the strength outcome of the weld [14].

The way to determine the mechanical properties of the metal material is by conducting testing such as tensile testing, hardness testing, bend testing, impact testing, and so on [15]. These testings are included in the type of testing that is destructive [16]. Bend testing is performed tovisually determine the cracks andto determine the quality and welding defects of a material [17]. Welding defects include fusion areas, weld metal, HAZ andunaffected base metal [18]. There are two types of bend testing, namely root bend and face bend [19]. Low carbon steels can be welded by various welding methods [20]. Low carbon steels have good weldability and have a low weld crack sensitivity compared to other carbon steels [21]. Low carbon steels are the most common used due to their affordable price and superior mechanical properties such as tensile strength and toughness, and they are acceptable for many engineering applications [22]. Research on bend testing has been carried out by several researchers. For instance, miftahrur [23] conducted research with the aim of knowing the Effect of Low Hydrogen E7016 Electrode Storage Temperature on Bend testing Results of SS400 Carbon Steel Plate Welding Joints.The result of this study is the higher the storage temperature is, the better it will produce crack resistance. From this previous research, only bend testingwas done by the temperature treatment to electrode heating and heating treament to the material. Therefore, this study provides welding treatment with different current sources. This study aims to further reveal the effect of AC and DC on the bend testing of single V seam welding joints on steel material DIN 17100 Grade ST 44.

\section{METHOD}

This research was using experimental method. The object of research was the result of welding joints of low carbon steel plates DIN 17100 Grade ST 44 with $10 \mathrm{~mm}$ thickness using SMAW. The electrodes used was E7016 with diameter of $\varnothing 2.6$ and $\varnothing 3.2 \mathrm{~mm}$ using strong current of $90 \mathrm{~A}$ with direct penetration (DC-). The connection used in this study was a single seam V. The welding process on the sample was carried out with downhand position (1G). The treatment given was by using AC and DC welding. The research diagram can be seen in Figure 1.

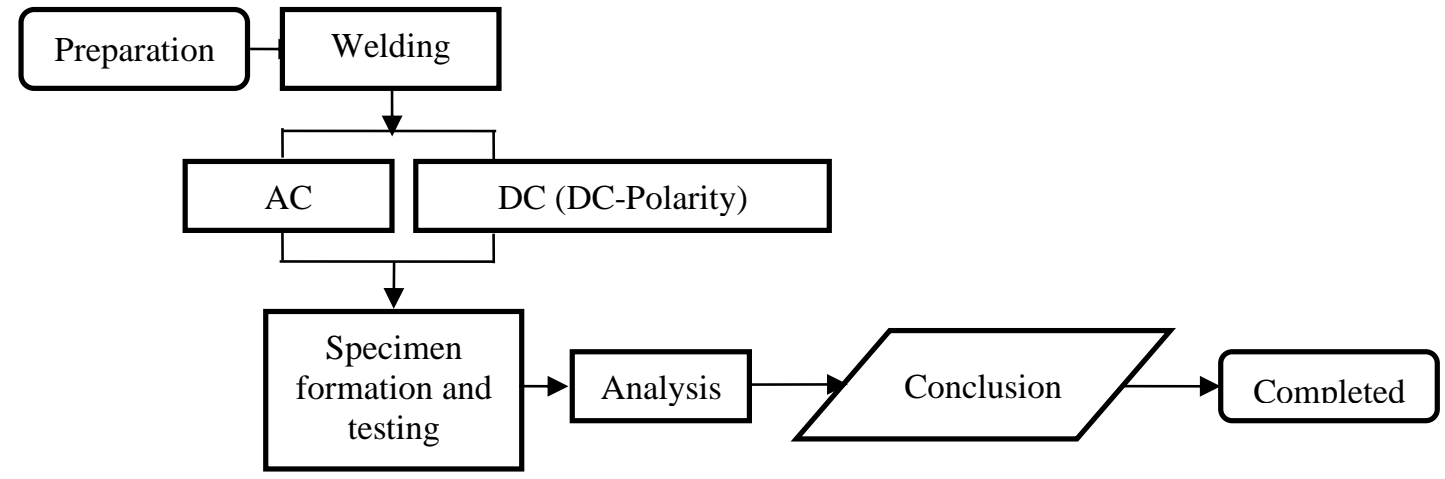

Figure 1 : Research diagram

The connection form used a single $\mathrm{V}$ groove with a weld angle of $60^{\circ}$, root face of $2 \mathrm{~mm}$ and root gap of $2 \mathrm{~mm}$ which was formed by a grinder anda file [24], as seen in Figure 2.

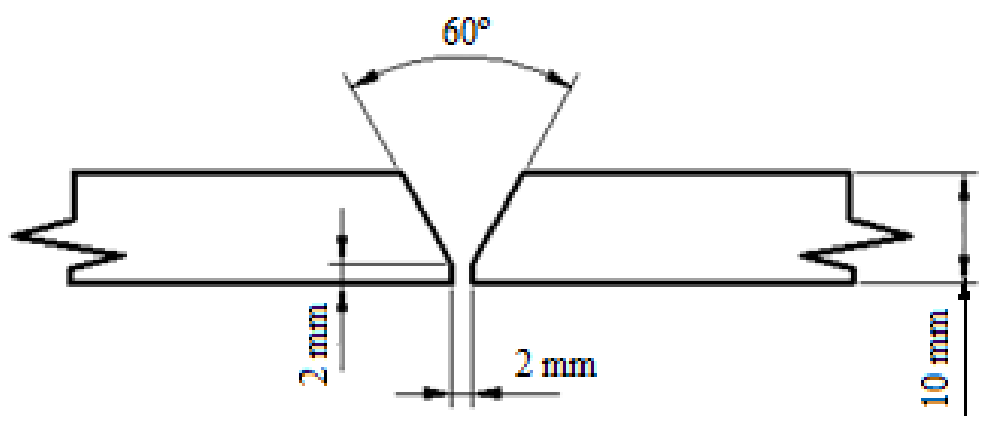

Figure $2: \mathrm{V}$ groove 
This study usedbend testing with two types of tests, namely root bend and face bend. Bend testing data was collected by measuring discontinuities or defects that occured on the curved surface of the test specimen.Then to state the test results either acceptable or not,it would be based on the acceptance criteria of the bend testing according to the AWS D1.1 standard, namely the curved surface does not exceed the discontinuity; (1) $3 \mathrm{~mm}$ measured in any direction on the surface, (2) $10 \mathrm{~mm}$ the sum of the greatest dimensions of all discontinuities exceeding $1 \mathrm{~mm}$, but less than or equal to $3 \mathrm{~mm}$, and (3) $6 \mathrm{~mm}$ maximum crack angle, except when the angle is cracks as the result of visible slag inclusions or other fusion type discontinuities, hence a maximum of $3 \mathrm{~mm}$ applies [25]. The specimens that had been joined were subsequently leveled by grinding the surface and the roots of the weld to produce a flat surface with the plate. Then it was formed into a bend testing according to the AWS D1.1 standard as shown below.
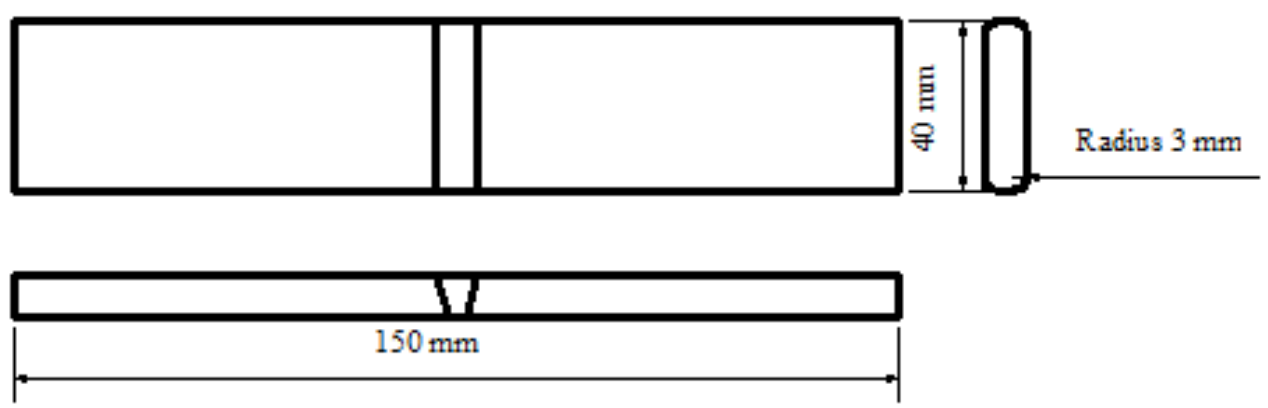

Figure 3 : AWS D1.1 Specimen Standard Face Bend and Root Bend [25].

\section{RESULTS AND ANALYSIS}

There are the results of bend testing data with AC and DC welding treatment. Figure 4 is the result of the bend testing, which was carried out to visually see the cracks that occur in the test specimen as seen below.

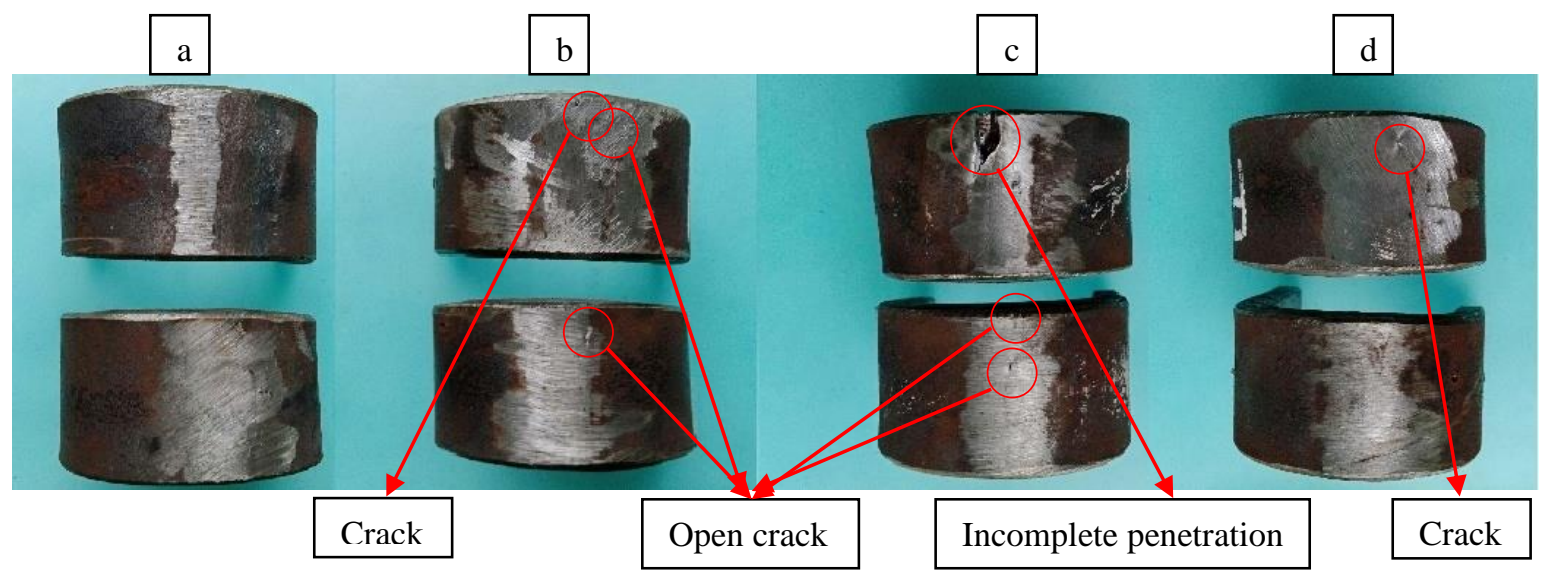

Figure 4 : Bend Testing Specimens

Figure 4 shows the specimens after the bend testing; figure (a) was the root bend test specimen with AC welding treatment, figure (b) was the face bend test specimen with AC welding treatment, figure (c) was the root bend test specimen with DC welding treatment, and figure (d) was face bend test specimen with DC welding treatment. It can be seen in Figure 4 that the specimen figure (a) had no cracks; in figure (b) there were crack and open crack, in figure (c) there were cracks with open crack defects and incomplete penetration, and in figure (d) there was crack defect. 
Table 1 : The data results of bend testing specimens

\begin{tabular}{|c|c|c|c|c|c|c|}
\hline \multirow[b]{2}{*}{ Treatmeant } & \multirow[b]{2}{*}{$\begin{array}{l}\text { Specimen } \\
\text { code }\end{array}$} & \multirow[b]{2}{*}{ Test type } & \multicolumn{3}{|c|}{ Information } & \multirow[b]{2}{*}{ The result } \\
\hline & & & $\begin{array}{l}\text { Kind of } \\
\text { defect }\end{array}$ & Size (mm) & Location & \\
\hline \multirow{4}{*}{$\begin{array}{c}\text { AC } \\
\text { Welding }\end{array}$} & A1 & Root Bend & - & - & - & Accepted \\
\hline & A2 & Root Bend & - & - & . & Accepted \\
\hline & A3 & Face Bend & $\begin{array}{c}\text { Crack } \\
\text { Open crack }\end{array}$ & $\begin{array}{l}2,2 \times 0,4 \\
1,6 \times 0,6\end{array}$ & HAZ & Accepted \\
\hline & A4 & Face Bend & Open crack & $1,7 \times 0,5$ & $\begin{array}{l}\text { Weld } \\
\text { metal }\end{array}$ & Accepted \\
\hline \multirow{4}{*}{$\begin{array}{c}\text { DC } \\
\text { Welding }\end{array}$} & B1 & Root Bend & $\begin{array}{l}\text { Incomplete } \\
\text { penetration }\end{array}$ & $14 \times 4,4$ & HAZ & $\begin{array}{c}\text { Not } \\
\text { Accepted }\end{array}$ \\
\hline & B2 & Root Bend & Open crack & $\begin{array}{l}1,6 \times 0,6 \\
1,9 \times 1,1\end{array}$ & HAZ & Accepted \\
\hline & B3 & Face Bend & Crack & $2,1 \times 0,4$ & $\begin{array}{l}\text { Weld } \\
\text { metal }\end{array}$ & Accepted \\
\hline & B4 & Face Bend & - & - & - & Accepted \\
\hline
\end{tabular}

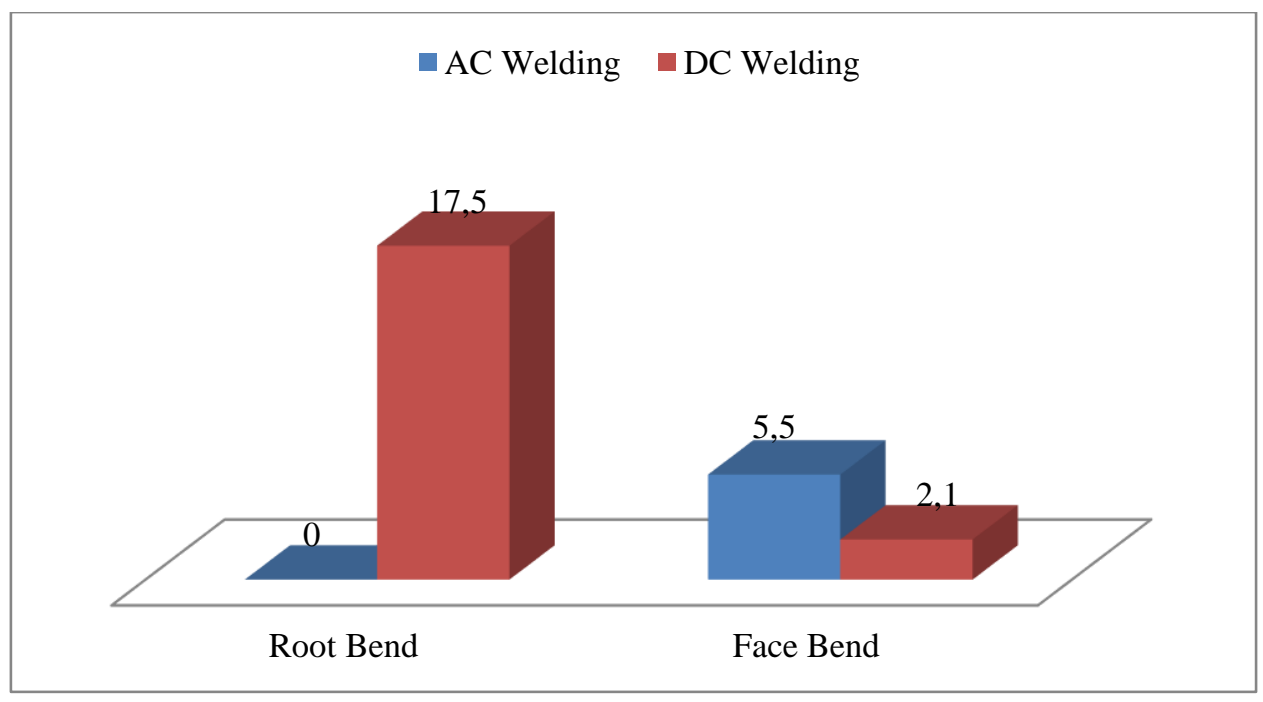

Figure 5 : Graph of the Total Crack Length of Bend Testing Results

From the results of bend testing (of the root bend and face bend) with AC welding treatment, the root bend test results of specimens A1 and A2 had no cracks, but there were cracks in the face bend test results of A3 specimens and open crack defects in specimen A4. However, both of these tests were accepted because the cracks occurred did not exceed the bend testing acceptance criteria according to the AWS D1.1 standard. On the other side, There werethe results of the root bend and face bend testings with DC welding treatment. From the results of the root bend tests, there were cracks in specimen B1 with open crack defects which were accepted and specimen B2 with incomplete penetration defects were declared unacceptable because the cracks occurred exceed the criteria for the acceptance of the appropriate bend testing AWS D1.1 standard. In the face bend test, there were crack defects in specimen B3, but there was no cracks in specimen B. These two tests were accepted because the cracks occurred did not exceed the criteria for acceptance of the bend testing according to the AWS D1.1 standard.

Based on the results of the face bend testing data, it shows that the two treatments given were accepted. In the root bend testing results, the AC welding was accepted, while the DC welding was not accepted based on the AWS D1.1 standard. After being tested, there were cracks with each size $<3 \mathrm{~mm}$ and the number of cracks $<10 \mathrm{~mm}$ which can be seen in table 2 , based on the standard, only cracks in the root bend on DC welding were declared unacceptable while others were declared accepted. In short, from the results of the data, this test shows a difference in the crack resistance of the welding joint from the type of current used through the root 
bend test and face bend test. The crack resistance in the AC root bend test is better than the DC root bend test, whereas the crack occured in DC face bend test is better than the AC face bend test.

\section{CONCLUSION}

Based on the data analysis and the discussion of bend testing in this study, the results of the bend testing showed that the AC welding root bend test specimen held no cracks while the DC welding root bend test held cracks with incompelete penetration and open crack defects. On the contrary, the AC welding face bend test had open crack defects and in the DC welding face bend test was found a crack. Thus, there was a difference in the crack resistance of the welding joint from the types of current used through the root bend test and face bend test. Therefore, it can be summarized that AC welding is better for root welding and DC welding is good for capping welding.

\section{REFERENCES}

[1] B.V.M.Engineering College, V.V. Nagar, Anand,Gujarat. Review for Design of Gripper in Universal Testing Machine.International Journal for Scientific Research \& Development.2016; Vol 4(1).

[2] Munawar et al. The Effects of Shielded Metal Arc Welding (SMAW) Welding On TheMechanical Characteristics With Heating Treatment inn S45c Steel. Journal of Physics: Conference Series. 2018. doi :10.1088/1742-6596/962/1/012063.

[3] Bodude, MA., Momohjimoh, I., Studies on Effects of Welding Parameters on the Mechanical Properties of Welded Low-Carbon Steel. Journal of Minerals and Materials Characterization and Engineering. 2015; Vol 3: 142-53.

[4] Hendri, N.,Yolli, F., Meisuri, H.Analysis of Tensile Strength the Fiber Bagasse Particles Board with Resin Adhesives. Teknomekanik.2018; Vol.1(1): 1-5. https://doi.org/10.24036/tm.v1i1.172

[5] Harsono Wiryosumarto, T. O. Teknologi Pengelasan Logam. Jakarta: Pratya Pramita. 2008.

[6] Despa Wandri., Purwantono., Pengaruh Arus AC dan DC terhadap Hasil Pengelasan pada Las Busur Listrik. Jurnal Pendidikan Teknik Mesin. 2016 : 1-7.

[7] Arifin. Las Litrik dan Otogen. Jakarta: Ghalia Indonesia; 1997

[8] Daryanto. Teknik Las. Bandung: Alfabeta; 2014

[9] Jeffus, L. Welding and Metal Fabrication. United States of America: Cengage Learning; 2012.

[10] Widharto, S., Welding Inspection. Jakarta: Mitra Wacana Media; 2013.

[11] Devendra Yadav \& Abhishek Gaikwad. Comparison And Testing Of Tensile Strength For Low \& Medium Carbon Steel. International Journal of Mechanical Engineering (IJME). 2015;Vol.4(5) : 1-8.

[12] Wari, A., Nurdin, H., \& Ya, K. Porosity Defect Analysis in ST 37 Steel Welding Joints Using the Dye Penetrant Method. Teknomekanik. 2020; Vol (1) : 1-8. https://doi.org/10.24036/tm.v3i1.5272

[13] M. Agung P., Jasman, Nelvi, E., Yolli, F. The Variation Effectof Electric Current Toward Tensile Strength on Low Carbon Steel Welding with Electrode E7018. Teknomekanik. 2020; Vol.3(1) : 917.https://doi.org/10.24036/tm.v3i1.5572

[14] Odebiyi, O.S., Adedayo, S.M., Tunji, L.A., Onuorah, M.O., A Review of Weldability of Carbon Steel in Arc-Based Welding Processes. Cogent Engineering. 2019; 6 (1) : 1-32.

[15] M. U. Deshpande, J. M. Kshirsagar, Dr. H. M. Dharmadhikari. Optimization of GMAW Process Parameters to Improve the Length of Penetration in EN 10025 S 235 Grade. Journal of Welding and Joining. Vol.32 (1)..

[16] Hendronursito Y, Isnugroho K, Birawidha DC, Amin M. Analysis Of Shielded Metal Arc Welding (SMAW)On HighManganese Steel Hammer-mill Crushe. Journal of Mechanical Engineering. 2019; Vol.16 (2).

[17] Ameen A. Nassar, Rafil M. Lefta and Muthanna J. Abdulsada. Experimental Study of The Effect of Welding Electrode Types on Tensile Properties of Low Carbon Steel Aisi1010. Kufa Journal of Engineering.2018; Vol. 9(4) : 163-173.

[18] Dadi, A., Goyal, P.B., Patel, M.H., A Review Paper on Optimization of Shielded Metal Arc Welding Parameters for Welding of (Ms) Sa-516 Gr.70 Plate by Using Taguchi Approach. International Journal of Scientific Research in Science and Technology. Vol 4(5): 1536-43. 2018. 
[19] Wibowo, H., Surahmanto, F., Peningkatan Kekuatan Mekanis dan Ketahanan Retak Las pada Sambungan Las Busur Elektroda Terbungkus Melalui Pemanasan awal pada Elektroda. Prosiding Seminar Nasional Rekayasa Teknologi Industri dan Informasi ke-6. 2011.

[20] Nutalapati, S., Azad, D,D., Naidu, D.G.S., Effect of Welding Current on Welding Speed and Ultimate Tensile Strenght on (UTS) of Mild Steel. International Journal of Mechanical Enggineering and Tecnology. 2016; Vol 7: 156-76.

[21] Jasman, J., Irzal, I., Adri, J., \& Pebrian, P. Effect of Strong Welding Flow on the Violence of Low Carbon Steel Results of SMAW Welding with Electrodes 7018. Teknomekanik. 2018; 1 (1) : 24-31. https://doi.org/10.24036/tm.v1i1.972

[22] Devendra Yadav \& Abhishek Gaikwad. Comparison And Testing Of Tensile Strength For Low \& Medium Carbon Steel. International Journal of Mechanical Engineering (IJME). 2015; Vol.4(5) : 1-8.

[23] Miftahrur B. Afan.,dkk., Pengaruh Suhu Penyimpanan Eloktroda Low Hydrogen E7016 terhadap Hasil Uji Tekuk Sambungan Las Pelat Baja Karbon SS400. Jurnal Rekayasa Mesin. 2020; Vol 15: 2025.http://dx.doi.org/10.32497/jrm.v15i1.1823

[24] Nazli, EzgiI, Peka., Faruk, Elaldi.Analysis of Welding Groove Angle and Geometry on Strength of Armor Steel. Materials and Manufacturing Processes.2012; Vol $\quad$ (27) 12: 1437 1441.https://doi.org/10.1080/10426914.2012.709343

[25] American Welding Society. Structural Welding Code-Steel. D1.1/D1.1M. 2015. 